\title{
CRIMINAL LAW - OBSCENITY - TEST TO BE USED IN DETERMINING - RELEVANCE OF EXPERT OPINION
}

\author{
Leonard H. Leach, Third Year Lap
}

\section{Introduction}

The secent case of Regina v. American News' once more gives opportunity for a commentator to say a few words about one of the most vexed areas of the Criminal law, the censorship of obscene literature. In the American News case, the accused firm was convicted before a County Court of the offence of having in its possession for the purpose of distribution, obscene written matter consisting of 117 copies of a book entitled Episode by Peter Denzer, contrary to section 150 (1) (a) of the Criminal Code. ${ }^{2}$ The accused firm appealed from conviction and the appeal was dismissed. The actual decision may be put on the footing that a conviction at trial will not be reversed unless there was misdirection, or unless the evidence was clearly insufficient to support the findings. ${ }^{3}$ However, by way of dictum at least, the Court of Appeal for Ontario laid down several sweeping propositions of law which deserve the closest examination.

\section{The Test}

The test for obscenity adopted by the court is that of Cockburn L.C.J. in $R$. v. Hicklin:

Whether the tendency of the matter charged as obseene is to deprave and corrupt those whose minds are open to such immoral influences and into whose hands a publication of this sort may fall.

The essence of the Hicklin test is stated to be the tendency to deprave and corrupt. It is in this area that most of the uncertainty in the law exists, for the Court is faced with a double hurdle: what is a tendency to depravity and corruption, and whom must it affect? The Court in the present case held that depravity and corruption may be the suggestion of impure and libidinous thoughts, or the influencing of some persons to commit impure acts, or the tendency to imperil the prevailing standards of public morals. These criteria for determining whether a tendency to deprave and corrupt exists are difficult of application for they are, as perhaps they must be, both difficult and vague. In the era of modern psychology, a person would indeed be foolhardy who would venture an opinion whether a thought be impure or not. Indeed, this is quite likely to be a purely subjective reaction dependant upon the moral atmosphere in which the reader happens to have been steeped. St. John-Stevas in Obscenity and the Law suggests that such thoughts must be of an impure or lecherous nature, not merely sexual." American courts would appear to lay

${ }^{1} R$. v. A merican News (1957) 118 C.C.C. 152.

2Criminal Code section 150(1) (a) provides: "Every one commits an offence who (a) makes, prints, publishes, distributes, circulates, or has in his possession for the purpose of publica. ation, distribution or circulation any obscene written matter, picture, model, phonograph record or other thing whatsoever....

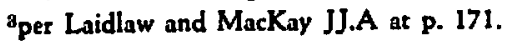

1 (1868) L.R. 3 Q.B. 360.

ON. St. John-Stevas: Obscenity and the Law, Martin Secker and Warburg, London 1956, at p. 126. 
more stress on a tendency to commit impure acts, ${ }^{\circ}$ though it is far from clear how this approach would be any more helpful than the first, more particularly when with legislation such as ours which is in the nature of a prior restraint, little factual evidence of such a tendency is likely to be forthcoming. ${ }^{7}$ A tendency to impair the prevailing standards of public morals is quite as vague as the other criteria. It is far from easy to ascertain the state of public morals at any one time, but an even greater difficulty is that a book, said to be obscene, may be an attempt to portray with some accuracy, the prevailing standards of public morals. It is not suggested that the judiciary in attempting to employ the tests relied on in the present case is wrong; or that there is a panacea available which will infallibly tell the Court whether a book be obscene or not, but rather that in branding a book as obscene, the Court should realize that its decision will inevitably depend largely on subjective factors, and that, therefore, the greatest caution should be exercised in reaching a decision. ${ }^{8}$

On the question of whom the tendency to deprave or corrupt must affect, a very wide divergence of judicial opinion may be found. Both Cockburn L. C. J. in Hicklin, and the Court of Appeal in the present case, were of the opinion that the tendency to deprave and corrupt referred to any person likely to be exposed to the book in question and that the test of obscenity was designed to protect the youth of the nation and other persons more susceptible to influence by such literature than the normal man or woman. This approach to the problem has aroused bitter critisism, ranging from reasoned argument to invective. Thus Professor Laskin has stated of the Hicklin definition: ${ }^{0}$

It is so wide and loose that almost any writing with a sexual content which excites the animosity of a knave or upsets the susceptibilities of a fool can be brought within its bounds.

No doubt society must protect the child, but surely we must not censor books down to the consistency of pablum to do so. Almost all persons are in agreement that smut ought to be suppressed, but an honest book, though it be a bit strong, is surely in a different category. ${ }^{10}$ We now have provisions aimed at the "crime comic"." Surely, with these, we can afford to be rather less solicitous of the welfare of the adolescent and pay greater heed to the more mature segment of society. It is, I submit, somewhat improbable to assume that a normal child will spend hours looking through a book, particularly one written with a serious purpose, in the distant hope of finding an aphrodisiac passage. ${ }^{12}$

OStevas, op. dit. at p. 127.

TLegislation invoking prior restraint is forbidden in the United States, so that presumably factual evidence of such a tendency could be forthcoming. $41 \mathrm{Minn}$. $L$. Rer, 122.

8See $38 \mathrm{Minn}, L$. Rev. $295 \mathrm{et}$. seq, for a discussion of the reasons underlying many decisions on obscene libel.

922 Can. Bar. Rev. 553.5; See also $38 \mathrm{Minn}$. L. Rev. 295 et. seg.; 52 Harv. L. Rev. $40-76$ "By the obscenity test as at present, the most intelligent and cultured member of the community would be reduced to the same plane as their most mentally immature and lewd members. No mater how high a man's head it would always be placed on the same level as another's feet."; 34 Cornell L.Q. 442; 32 Can. Bar. Rev. 1010.

10 Stevas, op. cit. introduction at $p$. xv by Sir A. P. Herbert.

${ }^{11}$ Criminal Code, section 150 (1) (b).

12See 34 Cornell L. Q. 442, a case note noting Re Worthington, 30 N.Y. Supp. 361 (1894) which upheld the sale of the Arabian Nights, Fielding's Tom Jones, Ovid's Art of Love, and Boccaccio's Decameron on the grounds that the class of people in need of statutory protection would be unlikely to buy or appreciate such works. 
Such an assumption ought not to be allowed to interfere with the free and unimpeded dissemination of serious literature.

Attempts to restrict the meaning of the phrase "tendency to deprave and corrupt" to the mature and normal element of society have been made in recent years. The way was pointed by the famous Ulysses decision some years ago. ${ }^{23}$ The tendency to deprave and corrupt must, held Judge Woolsey: ${ }^{1+}$

be tested by the Court's opinion as to its effect on a person with average sex instinets-what the French would call l'bomme moyen sensuel-who plays in this branch of legal inquiry, the same role of hypothetical reagent as does the 'reasonable man' in the law of tores.

Judge Woolsey recognised a danger in this test-that the reagent might be made subservient to the beliefs of the trier of fact. It is submitted that the danger is rather increased where there is no reagent at all. In the result, the learned judge held that while Ulysses might be an emetic, it was not an aphrodisiac, and so admitted it into the United States. Judge Woolsey's approach has since found wide acceptance in the United States, but has rarely been followed in other common law countries.

The direction to the jury given by Stable J. in R. v. Martin Secker and Warburg, however, deserves some comment. ${ }^{15}$ In that case, Stable J., in addressing the jury, employed the Hicklin test, but substantially agreed with Judge Woolsey that literary standards are not to be judged by the suitability of a work for the adolescent. Stable J. pointed out quite clearly that many of our greatest classics would be wholly unsuitable for reading by the adolescent. A mass of literature, said his Lordship, ${ }^{10}$

great literature, from many angles is whoily unsuitable for reading by the adolescent, but that does not mean that the publisher is guilty of a criminal offence for making those works available to the general public.

St. John-Stevas notes that this direction was thought to be, by literary circles, a declaration of independence from the prudish. ${ }^{17}$ Unfortunately, Stable J's decision has been more often dissented from than followed, and in the American News case was positively discountenanced, reliance being placed upon a decision of Lord Goddard C.J. upholding the traditional viewpoint. ${ }^{18}$ The court in the present case did concede that whether a book acts as an aphrodisiac or not is to be judged by modern standards but unfortunately, the amount of worldly wisdom to be imputed even to the modern schoolgirl appears minimal. On the whole, the judicial approach to the Hicklin rule, as well as the rule itself, appears to be wanting.

\section{Defences}

If a book be found obscene, the only defence to a charge under section $150(1)(a)$ is that the acts constituting the alleged offence served the public

19Unised States v. One Book entitled Ulysses... Both ttial and Appeal decisions are given in the Bodley Head edition, 1937 rp. 1952.

14Bodley Head edition at p. 753.

28R. v. Martin Secker and Warburg, [1954] W.L.R. 1138.

${ }^{10}$ Cited in Stevas op. cit. at p. 114.

${ }^{17}$ Stevas op. cit. at p. 116.

18R. v. Reiter, [1954] 2 Q.B. 16. 
good. Whether the public good was served or not is a question of law for the judge to decide. ${ }^{19}$ Like the definition of obscenity, the definition of public good has been left to the common law. The accepted test is; that which is ${ }^{20}$

necessary or advantageous to religion or morality, to the administration of justice, the pursuit of science, literature or art, or other objects of general interest.

In the American News case, Laidlaw and MacKay JJ.A. stated that they had the greatest difficulty in applying the statutory defence to a charge of possession of a book for the purposes of distribution. ${ }^{21}$ This is readily understandable for the test, while in itself apparently clear and susceptible under different circumstances, of application, is not responsive in terms to the accepted Hicklin definition of obscenity. That being so, it is not an effective defence to a charge under section $150(1)$ (a), thus burdening the law of obscene libel in Canada with a latent ambiguity. The definition of obscenity speaks of the tendency of the matter charged, while section 150(3) speaks of the public good actually being served. If, under section 150 (1) (a), the material be seized before distribution, there is no foundation for the defence. The matter may tend to serve the public good, just as it may tend to deprave and corrupt, but in neither case could it actually do either. Thus if section 150 (1) (a) be used as a prior restraint and the sections are interpreted literally, the defence of public good is rendered nugatory. The Court of Appeal attempted to resolve this difficulty by interpreting section $150(3)$ in such a manner as to render the defence one of whether a book charged as obscene might serve the public good.

The Court of Appeal then characterized the defence of public good as being essentially one of opinion, and, since it is made a question of law, one for the Court to decide. Evidence of opinion was offered by the appellant to show that the book in question was not obscene, and that it had very definite literary merit. This evidence, given by several Canadian authors and critics of the very highest repute, was rejected; the Court holding that the evidence was mere opinion on a matter of opinion, and hence inadmissable. There can, I submit, be little doubt that this view is correct in so far as the evidence was tendered to disprove a tendency to deprave and corrupt. A tendency to deprave and corrupt is a matter upon which a judge may well be expected to have as valid an opinion as the most highly qualified artist. In practice, opinion evidence is excluded on the ground that the trier of fact is as competent to draw an inference from a fact as the witness. The expert witness, however, may on certain matters give evidence of opinion, for he is more qualified to do so than the trier of fact, and this advantage outweighs the disadvantage of possible bias. ${ }^{22}$ While this consideration may bear no weight when the Court is considering whether the matter charged has a tendency to deprave and

${ }^{19}$ Criminal Code, section 150(3) which provides: "No person shall be convicted of an offence under this section if he establishes that the public good was served by the acts that are alleged to constitute the offence and that the acts alleged did not extend beyond what served the public good."

20Instant case at p. 116 citing Stephen's Digest of the Criminal Law.

21Instant case at p. 171.

${ }^{2}$ See Cowen and Carter; Essays on the Law of Eridence (1956) at p. 162 ct. seq., calling for a general relaxation in theory as well as practice of the opinion rule. 
corrupt, I submit that the situation is otherwise when the Court is considering the defence of public good. Public good as a defence clearly embraces work which advances the pursuit of science, literature or art. It is my submission that in this field the judge as a trier of fact is in an unfavourable position vis - $\dot{a}-$ vis a qualified expert when determining whether a given work might advance the pursuit of science, literature or art. Why, then, ought the courts to refuse to recognise such a person as an expert witness and refuse to draw what help they can from his knowledge? The judiciary, in general, ${ }^{23}$ are not expected to be, and I submit are not, experts in the field of art appreciation, and unless they are very well versed in the field, cannot form any really sound opinion whether a work might tend to serve the public good. It is true that the statements of literary figures are opinion evidence and possibly faulty, but their opinions are, it is submitted, more likely to help than to hinder the judge who must, in the final analysis, decide. It is therefore submitted that such evidence of opinion should be made a matter of expert testimony and admitted as an exception to the opinion rule.

\section{Conclusion}

Regina v. American News is a valuable case, showing plainly the difficulties attendant on application of the present law of obscene libel in Canada. The present law of obscene libel is as much an anomaly here as it is in England. ${ }^{24}$ It is susceptible of great abuse and could possibly do harm to author, publisher and distributor alike. ${ }^{25}$ Rather than amend the present Criminal Code pro. visions piecemeal, it would, in my submission, be far more efficacious to repeal the entire law of obscene libel as it now stands and to insert entirely new provisions in the Criminal Code. When the present Code was enacted, Parliament had little indication as to how an improvement could be made. Now, however, a draft of the proposed British Obscene Publications Bill ${ }^{28}$ together with Mr. St. John-Stevas' valuable monograph have become available. If the Courts cannot revise the existing law, then a more appropriate time than the present for Parliament to act could scarcely be found.

29But see Datling J., Scintillae Juris.

2'Stevas, op. cit. Appendiz 1.

${ }^{25}$ Stevas op. cil, discussing D. H. Lawrence's The Rainbow at pp. 93-5.

${ }^{20}$ Stevas op. cit. Appendix 2. 